\title{
The Easterlin Paradox- The Haves, The Have-Nots and
}

\section{The Happiness}

\author{
Dr. Komila Parthi ${ }^{1 *}$, Ramanpreet Kaur $^{2}$
}

\section{ABSTRACT}

The past research claims that poverty has a broad negative impact on happiness of individuals. The money doesn't make you happier, but lack of money makes you sadder. It has been observed that the poor are more likely than the affluent to be exposed to stressful life events, such as unemployment, illness and victimization etc. Poverty is not only economic limitations of people, it also encompasses the dissatisfaction of psychological and psychosocial needs, which if met, would elevate well-being of individuals. This paper uses inductive approach to understand the economics of happiness and a feeling of powerlessness in poverty-stricken population and attempts to uncover how poverty leads to a lack of happiness.

Keywords: Happiness, Have-Nots, Poverty, Well Being.

Happiness is an end that all of us seek through various means. Many scholars have argued that the happiness is the ultimate goal of human action. For instance, Aristotle, in his book, Ethics, identified happiness as the chief and final good. The concept of happiness has been a subject of interest to social science researchers lately. Everybody in life desires happiness and this could come as a result of many factors including some socio-economic factors. Rich and poor alike strive for happiness. Happiness studies reveal that the individuals' increased income does not automatically lead to greater happiness. But being poor certainly decreases one's chance of being happy. The term happiness is sometimes used interchangeably with the term subjective wellbeing in literature. The concept of subjective well-being or happiness comprises of how people evaluate their lives, short term as well as long term. These evaluations include their emotional reactions to events, their moods, and also the judgments about their life satisfaction, marital relationship satisfaction and job-satisfaction etc. (Diener et al. 1993). There are two distinct perspectives that revolve around two distinct philosophies while attempting to define happiness and well being. The first of these is labelled as hedonism and asserts that well-being consists of pleasure or happiness. The second view asserts that well-being consists of more than just

\footnotetext{
${ }_{1}^{1}$ Assistant Professor, Postgraduate Department of Psychology, DAV College, Sector 10, Chandigarh

${ }^{2}$ Research Scholar, Department of Psychology, Panjab University, Chandigarh

*Responding Author

(c) 2016 I K Parthi, R Kaur; licensee IJIP. This is an Open Access Research distributed under the terms of the Creative Commons Attribution License (http://creativecommons.org/licenses/by/2.0), which permits unrestricted use, distribution, and reproduction in any Medium, provided the original work is properly cited.
} 
happiness. It lies instead in the actualization of human potentials This latter view has been termed as eudaimonism (Waterman 1993). It consists of the belief that well-being means fulfilling or realizing one's daemon or true nature. The Hedonism view states that the goal of life is to experience the maximum amount of pleasure. The Eudaimonism view on the contrary argues that true happiness is found in the expression of virtue-that is, in doing what is worth doing. Eudaimonic theory maintains that not all desires and not all their outcomes that an individual values would yield well-being when achieved. Some outcomes might not be good for people and might not promote wellness even though they are pleasurable.

Poverty is defined as a state characterized by ill-being and a lack of resources, inferior to wealth which is regarded as a state of abundance and well-being. The World Health Organization has described poverty as the greatest cause of suffering on earth. In Bridging the Gaps, the World Health Organization (1995) states, 'The world's most ruthless killer and the greatest cause of suffering on earth is extreme poverty.' This statement reveals how important poverty as a variable is in adversely affecting the health. Poverty is a multidimensional phenomenon, consisting of an inability to satisfy basic needs, lack of control over resources (powerlessness), poor health and a lack of education in addition to lack of many basic amenities of life. Poverty can have alienating and distressing effects on the individuals and of particular concern are the direct and indirect effects of poverty on are the emotional, behavioural and psychological problems in the affected individuals. Poverty has wide ranging negative consequences for quality of life. The poor are more likely than the well off to be exposed to stressful life events like unemployment and illness. Happiness varies directly with one's own income and inversely with the incomes of others. Karl Marx put it this way: 'A house may be large or small; as long as the surrounding houses are equally small it satisfies all social demands for a dwelling. But if a palace rises beside the little house, the little house shrinks into a hut' (as quoted in Lipset, 1960, p. 63). The defining experiences of the poor involve limited choices, an inability to make themselves heard, less or no control over what happens to them (powerlessness). Powerlessness is born from multiple, interlocking social and economic disadvantages, which, while operating together in combination with each other, make it difficult for the poor to escape poverty.

\section{REVIEW OF LITERATURE}

Researchers have studied whether high income individuals are happier and reported a correlation between higher income and greater happiness (Clark, 2008). The poor have to live with chronic strains such as economic hardship, frustrated aspirations and job-dissatisfaction (Kessler 1979; Liem and Liem 1978; Ross and Huber 1985; Williams 1990). These experiences are not only upsetting but they are also likely to lower individual's self-esteem and diminish their sense of control over life leading to a feeling of powerlessness (Pearlin et al., 1981; Mirowsky and Ross 1989). The poor also appear to have relatively fewer social resources to draw on, smaller social networks, less organizational involvement, and less frequent contact with friends and family as compared to the people with high income (Cochran et al., 1990; d'Abbs, 1982; Fischer, 1982; House et al., 1988). This is so may be because economically deprived people lack the economic 


\section{The Easterlin Paradox- The Haves, The Have-Nots and The Happiness}

resources to maintain extended social networks. Low socioeconomic status (SES) people find their social relationships less useful in coping with daily stressful life events than high SES individuals (House et al., 1988; Liem and Liem, 1978). Poverty is also linked with lower social support from immediate family members: poor marital relations, high risk of divorce, and general dissatisfaction with family life (Conger et al.,1990; Lewis and Spanier, 1979; Voydanoff and Donnelly, 1988).

As research reveals that poverty is associated with stress, chronic strains, low social support, and difficult marital relationships, it is not surprising that the poor also have a comparatively low level of psychological well-being. Dohrenwend and Dohrenwend (1974) and Haring et al. (1984) indicate that low SES correlates with with high rates of depression, mental illness, and low psychological well-being. Deprivation and abject poverty are found to be detrimental to happiness. The behavioral economics literature reveals that people value losses disproportionately to gains (Kahneman et al.,1999). Recent studies conducted at Michigan State University and University of British Columbia revealed that higher income is associated with experiencing less daily sadness, but has no bearing on daily happiness (Kushlev et al., 2015).

Some researchers obtained cross-section data on multiple countries. They based their results on comparisons. The results obtained indicated a much lower correlation between income and subjective wellbeing within a country as compared to between countries (Diener et al., 1999). There are researches that provide evidence that countries with higher income have higher average levels of well-being (Diener et al., 1995) revealing that individuals in richer countries, as well as richer individuals in one country, are slightly happier. The idea that happiness is caused by wealth is a fundamental belief in capitalistic societies (Martial,2006). Myriads of studies confirm that in poorer countries, income does act as a predictor of well being (Diener, 2009).

Other studies by some other researchers such as Achor (2010), Diener (2009), Maital (2006), and King (2006), are a part of the new research that supports the idea that happiness causes greater wealth. It is also noticed that one single factor may not be the one influencing the happiness in its entirety (Ebrahim et al. 2013; Diener and Selicman 2006; Møller and Radloff 2010; Tella and MacCulloch 2008; Van Boven, 2005; Buchanan and Csikszentmihalyi 1991; Lynn and Steel 2006). Many researchers have tried to understand the individual relationships between various demographic, sociological, psychological, and behavioral characteristics and self-assessments of happiness (Borrero et al. 2013). Different scholars have documented that income, education, marriage, health, employment, social participation, and positive feelings, all are directly correlated with happiness (Borrero et al. 2013; Clark, 2003; Frey and Stutzer, 2002; Di Tella et al., 1999; Ravallion and Lokshin 2001; Shin and Johnson 1978; Blanchflower and Oswald 2000; Easterlin 1974, 1995, 2001).

The studies also reveal that absolute and relative incomes are not the only economic determinants of happiness. Unemployment is also found to reduce happiness in the individuals 
(Clark and Oswald, 1994; Winkelmann and Winkelmann, 1998). Another index of economic insecurity is inflation. The countries with higher inflation display lower level of happiness (Di Tella et al., 2001). Furthermore, subjective well-being is influenced by many factors that are non-economic, such as age, sex, marital status, health status, education, religiosity etc. (Helliwell, 2002).

\section{THE EASTERLIN PARADOX}

Richard Easterlin was the first modern economist to examine the relationship between individual's assessment of happiness and his income (Hernandez-Murillo, 2010). Surveying 19 countries, Easterlin found out that within a country people with higher income reported being happier (also observed by Oswald, 1997; Diener et al., 2003). But the studies conducted across countries and over time have found very little, if any, relationship between increases in per capita income and average happiness levels of people. On average, wealthier countries (as a group) are found to be happier than poor ones (as a group). In these studies happiness appears to rise with income up to a point, but not beyond it. Yet even among the poorer and less happier countries, there is not a clear relationship between average income and average happiness levels, which suggests that many other factors might be at play. Easterlin's findings are a major breakthrough in happiness economics. Happiness Economics is an approach combining the techniques used by economists with those used by psychologists in assessing welfare. The surveys of the reported well-being of individuals across countries and continents are collected. The economics of happiness does not attempt to replace income-based assessment of welfare, instead to complement it with broader measures of well-being of individuals.

\section{CONCLUSION}

It can be concluded that richer individuals in the same country are only (if at all) slightly happier than their less advantaged poor co-citizens. The economic growth in many developed countries has not led to happier individuals. On the other hand, a high income allows people in modern societies to indulge in luxurious leisure activities, make purchase of the latest technological goods, and buy expensive cars and houses. The majority of individuals express explicit interest in obtaining a higher income level, signaling that leading a luxurious life is the ultimate goal for them. Those who are below poverty line or slightly above it, are grappling with the deprivation. The question arises, how can we address the relationship between poverty, powerlessness and happiness? To do this, we must work along with the communities to analyze and address the root causes of the poverty, deprivation and injustice which define the lives of the deprived lot of society. All government policies likely to have a direct or indirect effect on poor people should be evaluated in terms of their impact on these people. These policies should be formulated in such a way that by favouring those who are less well-off, such inequalities should be reduced from the society. The above findings challenge all those committed to working for poverty reduction. The realities of poor people's lives must inform policymaking at macro as well as micro levels. 


\section{REFERENCES}

Achor, S. (2010). The Happiness Advantage: The Seven Principles of Positive Psychology that Fuel Success and Performance at Work. New York: Random House. Inc.

Blanchflower, D.G., \& Oswald, A.J. (2000). Well-Being over Time in Britain and the USA. NBER Working Paper 7487. Cambridge, MA: National Bureau of Economic Research.

Borrero, S.,Escobar, A.B., Cortés, A.M., \& Maya, L.C. (2013). Poor and Distressed, but Happy: Situational and Cultural Moderators of the Relationship between Wealth and Happiness. Estudios Gerenciales, 29, 2-11.

Buchanan, R., \& Csikszentmihalyi, M. (1991). Flow: the Psychology of Optimal Experience (Book Review). Design Issues, 8(1), 80-1.

Clark, A.E., Fritzers, P., \& Shields , M.A. (2008). Relative income, happiness and utility: An explanation for Easterlin Paradox and other puzzles. Journal of Economic Literature, 46(1),95-144.

Clark, A.E. (2003). Unemployment as a Social Norm: Psychological Evidence from Panel Data. Journal of Labor Economics, 21(2), 323-51.

Clark, A. \& Oswald, A. (1994). Unhappiness and unemployment. Economic Journal, 104, 648659.

Cochran, M., Lamer, M. D., Riley, L., Gunnarssona, C. R., Henderson, L. (1990). Extending Families: The Social Networks of Parents and Their Children. Cambridge: Cambridge University Press.

Conger, R, .D., Elder, G.H, Lorenz, F.O., Conger, K.C., Simons, R.L., Whitbecks, L.B., Hucka, Melby, J.N. (1990). Linking economic hardship to marital quality and instability. Journal of Marriage and the Family, 52, 643-656.

d'Abbs,P. (1982). Social Support Networks. Melbourne Institute of Family Studies.

Diener, E., Weiting, N., Harter,J. \& Arora, R. (2009). Wealth and happiness across the world: material prosperity predicts life evaluation, whereas psychosocial prosperity predicts positive feeling. J Pers Soc Psychol., 99(1), 52-61. doi: 10.1037/a0018066.

Diener, E, \& Selicman, M.E.P. (2006). Measure for Measure: The Case for a National WellBeing Index. Science and Spirit, 17(2), 36-37.

Diener, E. (2003). The Relationship Between Income and Subjective Well-Being: Relative or Absolute?. Social Indicators Research, 28, 195-223.

Diener E., Sandvik, E., Seidlitz, L., \& M. Diener, M. (1993). The Relationship between Income and Subjective Well-Being: Relative or Absolute? Social Indicators Research, 28(3), 195-223.

Diener, E., \& Diener, C. (1996). Most People are Happy. Psychological Science, 7(3), 181-85.

Diener, E., Diener, M. \& Diener, C. (1995). Factors Predicting the Subjective Well-Being of Nations. Journal of Personality and Social Psychology, 69(5), 851-64.

Di Tella, J., MacCulloch, R.R. \& Oswald, J.A. (1999). How Do Macro-economic Fluctuations Affect Happiness?. Mimeo. Boston: Harvard Business School. 
Di Tella, R., MacCulloch, R. \& Oswald, A. (2001). Preferences over inflation and unemployment: evidence from surveys of happiness. American Economic Review, 91, 335-341.

Dohrenwend, B, .P., \& B. Dohrenwend.(1974). Social and Cultural Influences on Psychopathology. Annual Review of Psychology, 25, 417-452.

Easterlin, R.A. (1974). Does Economic Growth Improve the Human Lot? Some Empirical Evidence. In P.A. David, and W.R. Levin (eds), Nations and Households in Economic Growth. Redwood City, CA: Stanford University Press.

Easterlin, R.A. (1995). Will Raising the Incomes of All Increase the Happiness of All?. Journal of Economic Behavior and Organization, 27(1), 35-48.

Easterlin, R.A. (2001). Income and Happiness: Towards a Unified Theory. The Economic Journal, 111(473), 465-84.

Easterlin, R. A. (2003). Explaining Happiness, Proceedings of the National Academy of Sciences, 100(19).

Ebrahim, A., Botha, F. \& Snowball, J. (2013). Determinants of Life Satisfaction among Race Groups in South Africa. Development Southern Africa, 30(2), 168-85.

Fischer,C. (1982). To Dwell Among Friends. Chicago:University of Chicago Press.

Frey, B.S., \& Stutzer, A. (2002). What Can Economists Learn from Happiness Research?. Journal of Economic Literature, 40(2), 402-35.

Hernandez-Murillo, R. \& Martineck, C. (2010). The Dismal Science Tackles Happiness Data. Federal Reserve Bank of St. Louis Review.

Haring, M., Stock, W.A., \& Okun, M.A. (1984). A Research Synthesis of Gender and Social Class as Correlates Of Subjective Well-being. Human Relations,37, 645-657.

Helliwell, J. F. (2002). How's life? Combining individual and national variables to explain subjective well-being. Economic Modelling, 20, 331-360.

House, J. S., Umbersona, D., \& Landis, K.R. (1988). Structure and Processes of Social Support. (pp. 293-380) in Annual Review of Sociology, vol. 14, edited by W.R. Scott and J. Blake. Palo Alto: Annual Reviews.

Kahneman, D, Diener, E. \& Schwarz, N. (1999). Well-being: The Foundations of Hedonic Psychology. New York: Russell Sage.

Kessler, R .C. (1979). Stress, Social Status, and Psychological Distress. Journal of Health and Social Behavior, 20, 259-272.

King, L.(2006). Following a moral compass. The Costo Connection, 19.

Kushlev, K., Dunn, E.W. \& Lucas, R. E. (2015). Higher income is associated with less daily sadness but not more daily happiness. Journal of Social Psychological and Personality Science, 1 (9). doi: 10.1177/1948550614568161

Lewis, R.A., \& Spanier, G.B. (1979). Theorizing About the Quality and Stability of Marriage. (pp. 268-294) in Contemporary Theories About the Family-Vol. 1: Research-Based Theories, edited by W.R. Burr, R. Hill, F.I. Nye, and I.L. Reiss. New York: Free Press.

Liem, R. \& J. Liem. (1978). Social class and mental illness reconsidered: The role of economic stress and social support. Journal of Health and Social Behavior, 19,139-156. 
Lipset, S.M. (1960). Political Man: The Social Bases of Politics. Garden City, New York: Doubleday.

Lynn, M., \& Steel, P. (2006). National Differences in Subjective Well-Being: The Interactive Effects of Extraversion and Neuroticism. Journal of Happiness Studies, 7(2), 155-65.

Maital, S. (2006). Reclaiming Moral Sentiments. In Handbook of Contemporary Behavioural Economics and Developments, ed. Morris Altman, pp. 210-212. New York: M.E. Sharpe, Inc.

Mirowsky, J., \& Ross, C.E. (1989). Social Causes of Psychological Distress. New York: Aldine.

Moller, V., \& Radloff, S. (2010). Monitoring Perceptions of Social Progress and Pride of Place in a South African Community. Applied Research in Quality Life, 5 (1) , 49 -71.

Oswald, A. (1997). Happiness and Economic Performance, The Economic Journal, 107(445),1815-31.

Pearlin, L.I., Menaghan, E.G., Lieberman, M.A. \& Mullan, J.T. (1981). The Stress Process. Journal of Health and Social Behavior, 22, 337-356.

Ravallion, M., \& Lokshin, M. (2001). 'Identifying Welfare Effects from Subjective Questions'. Economica, 68(271), 335-57.

Ross, C.E., \& Huber, J. (1985). Hardship and Depression. Journal of Health and Social Behavior, 26, 312-327.

Shin, D.C., \& Johnson, D.M. (1978). Avowed Happiness as an Overall Assessment of the Quality of Life. Social Indicators Research, 5(1), 475-92.

Tella, R.D., \& MacCulloch, R. (2008). Gross National Happiness as an Answer to the Easterlin Paradox?. Journal of Development Economics, 86 (1), 22-42.

Van Boven, L. (2005). Experientialism, Materialism, and the Pursuit of Happiness. Review of General Psychology, 9(2), 132-42.

Voydanoff, P., \& Donnelly, B.W. (1988). Economic Distress, Family Coping, and Quality of Family Life. (Pp. 97-116) in Families and Economic Distress: Coping Strategies and Social Policy, edited by P. Voydanoff and L.C. Majka. Beverly Hills: Sage.

Waterman, A.S. (1993). Two Conceptions of Happiness: Contrasts of Personal Expressiveness (Eudaimonia) and Hedonic Enjoyment. Journal of Personality and Social Psychology, 64(4), 678-91.

Winkelmann, L. \& Winkelmann, R. (1998). Why are the unemployed so unhappy? Evidence from panel data. Economica, 65, 1-15.

World Health Organization, (1995). Bridging the Gaps. Geneva: WHO. 